\title{
Pengembangan LKPD berbasis multimedia interaktif pada materi kingdom monera
}

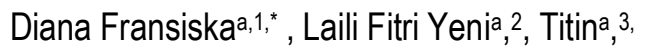 \\ a Program Studi Pendidikan Biologi, Universitas Tanjungpura, Pontianak, \\ 1. dianafransiska@student.untan.ac.id \\ * Corresponding Author
}

Received 7 Pebruari 2021; accepted 19 Pebruari 2021; published 19 Pebruari 2021

\begin{abstract}
ABSTRAK
Penelitian bertujuan untuk mengetahui pengembangan lembar kerja peserta didik berbasis multimedia interaktif pada materi kingdom monera Bentuk penelitian adalah research and development dengan prosedur yang mengacu pada model ADDIE yang meliputi tahap analyze, design, develop, implement dan evaluate. Penelitian ini dilakukan di 2 sekolah yaitu, MAN 2 Pontianak dan SMA Muhammadiyah 1 Pontianak dengan subjek penelitian sebanyak 12 orang peserta didik pada uji skala kecil dan 30 orang peserta didik pada uji skala besar. Instrumen yang digunakan adalah lembar validasi LKPD berbasis multimedia interaktif dan angket respons peserta didik. Hasil validasi LKPD berbasis multimedia interaktif materi kingdom monera adalah 0,98 sehingga dinyatakan valid. Hasil respons pada uji skala kecil $(77,28 \%)$ dengan kategori kuat. Sementara pada uji skala besar $(81,17 \%)$ dengan kategori sangat kuat. Berdasarkan hasil tersebut dapat disimpulkan bahwa LKPD berbasis multimedia interaktif layak digunakan sebagai bahan ajar pada materi kingdom monera dan mendapat respons dengan kategori sangat kuat.
\end{abstract}

\section{Development of interactive multimedia-based learners worksheet on kingdom monera material}

The study aims to find out the appropriateness of the interactive multimedia-based students' worksheet on the kingdom monera material. The form of this research is research and development with procedures involving ADDIE models that contain analyze, design, develop, implement and evaluate. The instrument used was a validation sheet of LKPD interactive multimedia-based and students questionnaire responses. The validation result of LKPD on interactive multimedia kingdom monera material is 0,98 so it is declared valid. The results of responses on a small scale obtained a value of $77,28 \%$ with a strong category. While the large scale test obtained a value of $81,17 \%$ with a very strong category. Based on the results of the study it can be concluded that the LKPD interactive multimedia-based is appropriate to be used as teaching material in the kingdom monera material and has received responses in a very strong category.
KATAKUNCI

Pengembangan, LKPD Berbasil Multimedia Interaktif, respons Kingdom monera

\section{KEYWORDS \\ Development, LKPD, Interactive Multimedia- based, Responses, Kingdom Monera}

This is an openaccess article under the CC-BY-SA license

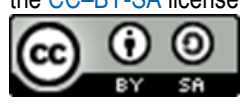

\section{Pendahuluan}

Perkembangan ilmu biologi tidak terlepas dari perkembangan ilmu pengetahuan dan teknologi (IPTEK). Biologi dan IPTEK penting dan berpengaruh pada kehidupan manusia, terutama dibidang pendidikan. Teknologi menjadi peluang bagi institusi pendidikan untuk melaksanakan pembelajaran 
yang bisa digunakan di komputer maupun smartphone (Budiman \& Nurbani, 2019). Guru dituntut untuk mampu mengikuti perkembangan IPTEK, agar bisa menjadi guru yang kreatif dan inovatif dalam proses pembelajaran sesuai dengan harapan kurikulum 2013 (Manisa, Aryati, \& Marlina, 2018; Rahmi, Hartini, \& Wati, 2014). Selain itu, peserta didik juga dituntut untuk aktif dan mandiri ketika belajar (Hasanah, 2020). Keberhasilan guru dalam menerapkan kurikulum 2013 dengan menggunakan pendekatan saintifik tidak lepas dari bahan ajar yang digunakan (Elwi, Festiyed, \& Djamas, 2017). Tanpa bahan ajar guru dan peserta didik akan kesulitan dalam meningkatkan efektivitas pembelajaran (Haryanti, Septiana, Lestariningsih, \& Lestariningsih, 2020). Bahan ajar yaitu suatu bahan yang digunakan untuk membantu guru dan peserta didik dalam proses pembelajaran (Prastowo, 2015; Syamsurizal, Epinur, \& Devi Marzelina, 2017). Salah satu bahan ajar yang bisa digunakan guru ialah Lembar Kerja Peserta Didik (LKPD). Lembar kerja peserta didik ialah bahan ajar yang dapat mengoptimalkan proses pembelajaran (Pariska, Elniati, \& Syafriandi, 2012).

Upaya meningkatkan pemahaman peserta didik dan membuatnya aktif dalam belajar maka perlu adanya bahan ajar yang bersifat interaktif. Salah satunya yaitu LKPD berbasis multimedia interaktif pada materi kingdom monera. Multimedia ialah beberapa media berbasis komputer dan sistem komunikasi yang mempunyai peran untuk menyimpan dan menerima informasi yang berbentuk teks, audio, video, grafik dan sebagainya (Munir, 2013). Multimedia interaktif yaitu multimedia yang terdiri dari alat pengontrol yang dapat dioperasikan, selain menyajikan materi, dilengkapi juga dengan video dan animasi sehingga pengguna dapat memilih sesuai keperluannya yang dapat menambah pemahaman peserta didik dalam mempelajari materi yang disampaikan (Munir, 2013; Nufus, Khadun, \& Nazar, 2018; Rokhmah, Gulo, \& Edi, 2017; Subiyantoro \& Nugroho, 2018). LKPD berbasis multimedia interaktif terdiri dari materi dan latihan yang berupa soal-soal berbasis komputer, peserta didik dituntun untuk belajar secara mandiri hanya dengan mengikuti petunjuk pengaplikasian produk tersebut (Prianoto, Gulo, \& Effendi, 2017).

Berdasarkan hasil wawancara yang dilakukan pada tiga sekolah yaitu SMA Muhammadiyah 1 Pontianak, MAN 2 Pontianak dan SMA Mujahidin Pontianak diperoleh informasi bahwa Lembar Kerja Peserta Didik (LKPD) materi kingdom monera yang digunakan guru masih berbasis cetak yang dibagikan kepada peserta didik. Di SMA Muhammadiyah 1 Pontianak, guru membuat sendiri LKPD dan di MAN 2 Pontianak dan SMA Mujahidin Pontianak guru menggunakan LKPD yang dicetak oleh penerbit. LKPD guru sudah baik, namun belum lengkap, karena belum memuat semua komponen dari LKPD.(Prastowo, 2015) menyatakan bahwa struktur LKPD tersusun dari 6 komponen yaitu judul, kompetensi yang akan dicapai, petunjuk belajar, informasi, tugas dan langkah kerja, serta penilaian. Minimal keenam komponen inti tersebut harus ada ketika membuat LKPD.

Berdasarkan analisis silabus, materi kingdom monera merupakan materi yang dipelajari oleh peserta didik di kelas X SMA/MA yaitu pada KD 3.5 yang berisi menganalisis struktur dan cara hidup bakteri serta peranannya dalam berbagai aspek kehidupan masyarakat. Adapun submateri yaitu struktur dan reproduksi bakteri, klasifikasi bakteri, menginokulasi bakteri/ pour steak/streak plate, pengecatan gram dan peran bakteri dalam kehidupan. Peneliti memilih materi kingdom monera dikarenakan pada hasil wawancara dengan guru biologi di MAN 2 Pontianak, SMA Muhammadiyah 1 Pontianak dan di SMA Mujahidin Pontianak menyatakan peserta didik kurang memahami materi kingdom monera. khususnya pada konsep mendeskripsikan karakteristik bakteri, menjelaskan perkembangbiakan bakteri, mengidentifikasi dasar pengelompokan bakteri, menjelaskan inokulasi bakteri dan macam-macam pengecatan gram.

Lembar Kerja Peserta Didik (LKPD) berbasis multimedia interaktif yang dikembangkan ini, dibuat menggunakan Software Hot Potatoes dan Web Pages Maker untuk membuat LKPD menjadi lebih interaktif. Beberapa kelebihan dari LKPD berbasis multimedia interaktif materi kingdom monera ini adalah berbasis teknologi, mampu memvisualisasikan materi kingdom monera dengan jelas, mampu menggabungkan antara teks, gambar, audio, animasi gambar atau video dan musik, yang bergabung untuk saling mendukung pencapaian tujuan pembelajaran materi kingdom monera, menghemat waktu

Diana Fransiskaa, Laili Fitri Yeni, Titin (Pengembangan LKPD berbasis multimedia interaktif pada materi kingdom monera) 
agar peserta didik bisa mengerjakan sendiri, serta LKPD disajikan dalam bentuk offline (tidak menggunakan internet). Visualisasi dapat mempermudah peserta didik dalam memahami materi pembelajaran (Arahim, 2018)

Tujuan dari penelitian ini yaitu untuk mengetahui pengembangan lembar kerja peserta didik berbasis multimedia interaktif pada materi kingdom monera, yang diharapkan akan mempermudah guru dalam mengefesienkan waktu dan untuk mempermudah peserta didik memahami materi pelajaran. Berdasarkan latar belakang tersebut, maka diperlukan inovasi untuk mengembangkan lembar kerja peserta didik berbasis multimedia interaktif pada materi kingdom monera.

\section{Method}

Metode penelitian dengan bentuk penelitian dan pengembangan (research and development) yang digunakan dalam penelitian ini adalah model ADDIE yang meliputi tahap analisis (analyze), desain (design), pengembangan (develop), implementasi (implement) dan evaluasi (evaluate) (Branch, 2009; Hasyim, 2016). Subjek dan lokasi uji coba penelitian pengembangan lembar kerja peserta didik berbasis multimedia interaktif pada materi kingdom monera adalah kelas X SMA/MA. Subjek ini berasal dari 2 sekolah yang ada di Pontianak yakni MAN 2 Pontianak dan SMA Muhammadiyah 1 Pontianak. Teknik yang digunakan dalam pengambilan subjek yaitu menggunakan teknik purposive sampling, dalam penelitian ini, peneliti melakukan uji coba terbatas dan uji coba lapangan. Menurut (Sadiman dkk, 2014) uji skala kecil memerlukan 10-20 peserta didik, sedangkan uji coba lapangan sekitar 30 peserta didik. Uji coba terbatas subjek yang digunakan peneliti berjumlah 12 orang, sedangkan untuk uji coba lapangan subjek yang digunakan peneliti berjumlah 30 orang. Peserta didik yang dipilih dalam penelitian ini dengan kategori kurang pandai, sedang dan pandai.

Instrumen penelitian merupakan alat yang digunakan untuk mengukur fenomena alam atau sosial yang diamati (Sugiyono, 2015). Instrumen yang digunakan dalam penelitian ini yaitu angket respons. Angket adalah daftar pertanyaan yang diberikan kepada subyek penelitian untuk memberikan respons sesuai dengan permintaan peneliti (Riduwan, 2015). Angket atau kuesioner merupakan pernyataan tertulis untuk mendapatkan informasi dari responden (Arikunto, 2013).

Uji keabsahan dalam penelitian ini yaitu dilakukan dengan uji validitas. Validitas merupakan derajat ketetapan antara data yang terjadi pada objek penelitian dengan daya yang dapat dilaporkan oleh peneliti (Sugiyono, 2015). Validitas dalam penelitian ini adalah validitas isi, ketika sebuah tes dikatakan memiliki validitas isi apabila mengukur tujuan tertentu yang sejajar dengan materi yang diberikan (Arikunto, 2013). Pada penelitian ini, LKPD berbasis multimedia interaktif di validasi oleh 9 validator yang terdiri dari 4 dosen pendidikan biologi dan 5 guru biologi sehingga diperoleh hasil 0,98 yang tergolong valid berdasarkan tabel nilai minimum lawshe untuk 9 validator.

Perhitungan validitas isi menggunakan rumus CVR (Content Validity Ratio) dengan rumus sebagai berikut (Lawshe, 1975):

$$
\mathrm{CVR}=\frac{\mathrm{ne}-\frac{1}{2} \mathrm{~N}}{\frac{1}{2} \mathrm{~N}}
$$

Setelah dihitung nilai CVR setiap kriteria kemudian dihitung nilai CVI (Content Validity Index) atau nilai rata- rata CVR secara keseluruhan untuk menggambarkan bahwa secara keseluruhan butir- butir instrumen mempunyai validasi isi yang baik.

Adapun rumus CVI adalah sebagai berikut:

$$
C V I=\frac{\Sigma C V R}{\Sigma n}
$$

Jika pada perhitungan akhir skor CVR dan CVI memenuhi nilai batas minimum (Lawshe, 1975) yaitu 0,75 maka bahan ajar LKPD berbasis multimedia interaktif dinyatakan valid dan layak digunakan.

Diana Fransiskaa, Laili Fitri Yeni, Titin (Pengembangan LKPD berbasis multimedia interaktif pada materi kingdom monera) 
Analisis respons dilakukan dengan menggunakan skala likert. Adapun langkah-langkah dalam menganalisis angket yaitu sebagai berikut : Memeriksa dan menghitung skor dari setiap jawaban yang dipilih oleh peserta didik pada angket yang telah diberikan; Merekapitulasi skor yang diperoleh tiap peserta didik. Dalam penelitian ini, perolehan skor untuk masing-masing jawaban adalah sebagai berikut : Sangat setuju (SS) $=4$, Setuju $(\mathrm{S})=3$, Tidak setuju $\quad(T S)=2$, Sangat tidak setuju (STS) $=1$ untuk pernyataan positif, sedangkan untuk pernyataan negatif adalah sebagai berikut: Sangat setuju $(\mathrm{SS})=1$, Setuju $(\mathrm{S})=2$, Tidak setuju $(\mathrm{TS})=3$, Sangat tidak setuju $(\mathrm{STS})=4$ (Riduwan, 2015); Menghitung interpretasi skor tiap item pernyataan dengan menggunakan persamaan sebagai berikut :

Interval $=\frac{\text { Skor item pertanyaan/pernyataan }}{\text { Skor tertinggi item pertanyaan/pernyataan }} \times 100 \%$

Menentukan rata-rata skor respons peserta didik berdasarkan kriteria dan menentukan kategori respons atau tanggapan yang diberikan peserta didik terhadap suatu kriteria dengan cara mencocokkan hasil persentase dengan kriteria positif yaitu: Angka 0\% - 20,99\% (Sangat Lemah), Angka 21\% - 40,99\% (Lemah), Angka 41\% - 60,99\% (Cukup), Angka 61\% - 80,99\% (Kuat), Angka 81\% - 100\% (Sangat Kuat), (Riduwan, 2015).

\section{Hasil dan Pembahasan}

Untuk mengetahui kelayakan LKPD berbasis multimedia interaktif pada materi kingdom monera sebagai bahan ajar di kelas X SMA/MA dilakukan uji validasi oleh 9 orang validator yang terdiri dari 4 orang dosen dan 5 orang guru. Lembar validasi yang digunakan terdiri dari empat aspek yakni kelayakan isi, kebahasaan, sajian dan kegrafisan.

Hasil validasi dari LKPD berbasis multimedia interaktif pada materi kingdom monera disajikan dalam Tabel 1 berikut:

Tabel 1. Hasil validasi LKPD berbasis multimedia interaktif pada materi kingdom monera oleh validator.

\begin{tabular}{|c|c|c|c|c|c|c|c|c|c|c|c|c|}
\hline \multirow[t]{2}{*}{ Aspek } & \multirow[t]{2}{*}{ Kriteria } & \multicolumn{9}{|c|}{ Validator ke- } & \multirow[t]{2}{*}{$C V R$} & \multirow[t]{2}{*}{ Ket } \\
\hline & & 1 & 2 & 3 & 4 & 5 & 6 & 7 & 8 & 9 & & \\
\hline \multirow[t]{4}{*}{ Kelayakan isi } & $\begin{array}{l}\text { 1. Isi LKPD berbasis multimedia interaktif } \\
\text { sesuai dengan kompetensi dasar, dan } \\
\text { tujuan }\end{array}$ & 3 & 4 & 3 & 3 & 4 & 4 & 4 & 3 & 4 & 1 & Valid \\
\hline & $\begin{array}{l}\text { 2. Materi yang disajikan didalam LKPD } \\
\text { berbasis multimedia interaktif sesuai } \\
\text { dengan konsep materi kingdom monera }\end{array}$ & 3 & 4 & 3 & 3 & 4 & 4 & 4 & 3 & 4 & 1 & Valid \\
\hline & $\begin{array}{l}\text { 3. LKPD berbasis multimedia interaktif } \\
\text { diperluan dalam proses pembelajaran } \\
\text { untuk menunjang terlaksanakanya proses } \\
\text { pembelajaran. }\end{array}$ & 3 & 4 & 3 & 3 & 4 & 4 & 4 & 3 & 4 & 1 & Valid \\
\hline & $\begin{array}{l}\text { 4. LKPD berbasis multimedia interaktif } \\
\text { diperlukan oleh peserta didik dalam } \\
\text { memahami materi kingdom monera }\end{array}$ & 2 & 3 & 4 & 3 & 4 & 4 & 3 & 3 & 4 & 0.78 & Valid \\
\hline \multirow[t]{4}{*}{ kebahasaan } & $\begin{array}{l}\text { 5. Pemilihan kosakata yang digunakan } \\
\text { didalam LKPD berbasis multimedia } \\
\text { interaktif mudah dipahami oleh peserta } \\
\text { didik }\end{array}$ & 3 & 3 & 4 & 3 & 4 & 3 & 3 & 3 & 4 & 1 & Valid \\
\hline & $\begin{array}{l}\text { 6. Informasi yang disajikan didalam LKPD } \\
\text { berbasis multimedia interaktif lengkap } \\
\text { dan jelas }\end{array}$ & 3 & 3 & 4 & 3 & 4 & 3 & 3 & 3 & 4 & 1 & Valid \\
\hline & $\begin{array}{l}\text { 7. Kalimat yang digunakan didalam LKPD } \\
\text { berbasis multimedia interaktif sesuai } \\
\text { dengan PUEBI }\end{array}$ & 3 & 3 & 3 & 3 & 4 & 4 & 3 & 3 & 4 & 1 & Valid \\
\hline & $\begin{array}{l}\text { 8. Kalimat yang digunakan didalam LKPD } \\
\text { berbasis multimedia interaktif efektif }\end{array}$ & 3 & 3 & 3 & 3 & 4 & 3 & 4 & 3 & 4 & 1 & Valid \\
\hline
\end{tabular}




\begin{tabular}{|c|c|c|c|c|c|c|c|c|c|c|c|c|}
\hline \multirow[t]{3}{*}{ Aspek } & \multirow[t]{2}{*}{ Kriteria } & \multicolumn{9}{|c|}{ Validator ke- } & \multirow[t]{2}{*}{ CVR } & \multirow[t]{2}{*}{ Ket } \\
\hline & & 1 & 2 & 3 & 4 & 5 & 6 & 7 & 8 & 9 & & \\
\hline & dan efisien. & & & & & & & & & & & \\
\hline \multirow[t]{3}{*}{ Sajian } & $\begin{array}{l}\text { 9. Tujuan pembelajaran didalam LKPD } \\
\text { berbasis multimedia interaktif jelas dan } \\
\text { isi LKPD mengacu pada tujuan yang } \\
\text { telah dibuat }\end{array}$ & 3 & 3 & 4 & 3 & 4 & 4 & 4 & 3 & 3 & 1 & Valid \\
\hline & $\begin{array}{l}\text { 10. Komponen LKPD berbasis multimedia } \\
\text { interaktif lengkap dan berurutan }\end{array}$ & 3 & 3 & 4 & 3 & 3 & 3 & 4 & 3 & 4 & 1 & Valid \\
\hline & $\begin{array}{l}\text { 11. Informasi yang ada di LKPD berbasis } \\
\text { multimedia interaktif lengkap dan dapat } \\
\text { menunjang peserta didik untuk } \\
\text { melakukan kegiatan didalam LKPD }\end{array}$ & 3 & 4 & 3 & 3 & 4 & 3 & 3 & 3 & 4 & 1 & Valid \\
\hline \multirow[t]{4}{*}{ Kegrafisan } & $\begin{array}{l}\text { 12. Jenis dan ukuran tulisan yang digunakan } \\
\text { didalam LKPD berbasis multimedia } \\
\text { interaktif sudah tepat sehingga dapat } \\
\text { dengan mudah dibaca oleh peserta didik. }\end{array}$ & 3 & 4 & 3 & 3 & 4 & 3 & 3 & 3 & 4 & 1 & Valid \\
\hline & $\begin{array}{l}\text { 13. Tata letak kalimat dan komponen LKPD } \\
\text { tepat sehingga memudahkan peserta } \\
\text { didik dalam proses pembelajaran }\end{array}$ & 3 & 3 & 4 & 3 & 3 & 3 & 4 & 3 & 4 & 1 & Valid \\
\hline & $\begin{array}{l}\text { 14. Pemilihan Gambar/foto dan video dapat } \\
\text { memperjelas informasi r } \begin{array}{r}\text { yang } \\
\text { disampaikan baik melalui bentuk } \\
\text { maupun warna }\end{array}\end{array}$ & 3 & 4 & 4 & 3 & 4 & 4 & 3 & 3 & 4 & 1 & Valid \\
\hline & $\begin{array}{l}\text { 15. Tampilan desain LKPD berbasis } \\
\text { multimedia interaktif menarik untuk } \\
\text { dibaca }\end{array}$ & 3 & 4 & 4 & 3 & 4 & 3 & 4 & 3 & 4 & 1 & Valid \\
\hline CVI & & 0,9 & & & & & & & & & & \\
\hline
\end{tabular}

Berdasarkan Tabel 1, semua kriteria LKPD berbasis multimedia memenuhi batas minimum (Lawshe, 1975) yaitu 0,75 untuk validator yang berjumlah 9 orang. Kelayakan LKPD berbasis multimedia interaktif pada materi kingdom monera yang diukur kelayakannya oleh 9 validator dengan 4 aspek yaitu kelayakan isi, kebahasaan, sajian dan kegrafisan. Nilai CVI yang didapatkan yaitu 0,98. Nilai tersebut menunjukkan bahwa LKPD berbasis multimedia interaktif layak untuk digunakan sebagai bahan ajar pada materi kingdom monera kelas X SMA/MA.

Pada aspek kelayakan isi terdiri dari empat kriteria yang mana tiga kriteria mendapatkan nilai CVR (Content Validity Ratio) yaitu 1 (valid) dan satu kriteria mendapatkan nilai CVR 0,78 (valid). Secara keseluruhan aspek kelayakan isi pada LKPD berbasis multimedia interaktif ini telah sesuai dengan kompetensi dasar dan konsep materi pembelajaran sehingga memberikan kemudahan bagi peserta didik dalam mempelajari materi kingdom monera. Hal ini sejalan dengan pendapat (Some, 2013), bahwa penggunaan media pembelajaran dengan basic teknologi memberikan dampak yang sangat positif bagi kemampuan dan kemauan peserta didik untuk mengikuti proses pembelajaran.

Aspek kebahasaan terdiri dari 4 kriteria yang secara keseluruhan mendapatkan nilai CVR (Content Validity Ratio) yaitu 1 (valid). Menurut (Ardiawan, 2016) faktor penting dalam pengembangan bahan ajar yaitu bahasa. Secara keseluruhan aspek bahasa pada LKPD berbasis multimedia interaktif sudah menggunakan bahasa yang komunikatif dan kata-kata yang telah disesuaikan dengan PUEBI sehingga dapat meningkatkan keterbacaan peserta didik terhadap LKPD berbasis multimedia interaktif serta memudahkan dalam memahami materi kingdom monera. Bahasa yang digunakan harus dipahami oleh peserta didik, yaitu dengan memperhatikan unsur-unsur yang mempengaruhi teterbacaan yakni susunan kata dan kalimat, tata cara penulisan kata, struktur paragraf, dan pilihan kata, sehingga peserta didik lebih mudah memahami pesan yang disampaikan dalam media (Sitepu, 2015; Syafrizal, Yeni, \& Titin, 2014). 
Aspek sajian terdiri dari 3 kriteria yang secara keseluruhan mendapatkan nilai CVR (Content Validity Ratio) yaitu 1 (valid). Aspek sajian pada LKPD berbasis multimedia interaktif ini telah sesuai dengan tujuan pembelajaran, komponen LKPD dan materi yang disajikan dalam LKPD berbasis multimedia interaktif juga lengkap. Hal ini sejalan dengan pendapat (Sitepu, 2015), kurikulum memuat tujuan pembelajaran dalam bentuk kompetensi yang diharapkan dapat dicapai oleh peserta didik setelah proses pembelajaran.

Aspek kegrafisan terdiri dari 4 kriteria yang secara keseluruhan mendapatkan nilai CVR (Content Validity Ratio) yaitu 1 (valid). Aspek kegrafisan pada LKPD berbasis multimedia interaktif ini telah disesuaikan antara jenis dan ukuran tulisan, tata letak kalimat, pemilihan gambar/foto dan video, serta tampilan desain LKPD. Susunan kalimat dan kata yang digunakan hendaknya sederhana, mudah terbaca, mudah dimengerti, singkat dan jelas. Selain mudah dipahami, penyampaian materi pada media pembelajaran juga harus interaktif (Nurdin \& Andriantoni., 2016).

Respons peserta didik yang dilihat dalam penelitian ini terdiri dari 19 pernyataan dan tersusun atas 3 aspek yakni aspek kognitif, afektif dan konatif. Setelah semua perangkat divalidasi oleh validator dan dinyatakan layak digunakan, penelitian dilanjutkan pada tahap evaluasi sumatif yang bertujuan untuk mengetahui kelayakan LKPD berbasis multimedia interaktif. Tahap ini dilakukan 2 kali, yaitu uji skala kecil dan uji skala besar.

Hasil analisis angket respons peserta didik terhadap LKPD berbasis multimedia interaktif pada tahap uji skala kecil dapat dilihat pada Tabel 2 berikut:

Tabel 2. Hasil analisis angket respons peserta didik terhadap LKPD berbasis multimedia interaktif pada tahap uji skala kecil.

\begin{tabular}{|c|c|c|c|}
\hline \multirow[t]{2}{*}{ Aspek } & \multirow[t]{2}{*}{ Indikator } & \multicolumn{2}{|c|}{ Respons peserta didik } \\
\hline & & Skala kecil & kategori \\
\hline \multirow[t]{3}{*}{ Kognitif } & Kemudahan dalam memahami isi LKPD & $77,91 \%$ & Kuat \\
\hline & Kesesuaian gambar dan video dengan materi & $77,08 \%$ & Kuat \\
\hline & Kejelasan petunjuk belajar dan informasi di dalam LKPD & $81,24 \%$ & $\begin{array}{c}\text { Sangat } \\
\text { Kuat }\end{array}$ \\
\hline Rata-rata aspek kognitif & & $78,74 \%$ & Kuat \\
\hline \multirow[t]{3}{*}{ Afektif } & Motivasi & $77,08 \%$ & Kuat \\
\hline & Rasa ingin tahu & $79,17 \%$ & Kuat \\
\hline & Kemenarikan & $74,99 \%$ & Kuat \\
\hline Rata-rata aspek afektif & & $77,08 \%$ & Kuat \\
\hline Konatif & $\begin{array}{l}\text { Kecenderungan untuk menggunakan LKPD berbasis } \\
\text { multimedia interaktif }\end{array}$ & $76.04 \%$ & Kuat \\
\hline Rata-rata aspek konatif & & $76.04 \%$ & Kuat \\
\hline Rata-rata secara keseluru & han & $77,28 \%$ & Kuat \\
\hline
\end{tabular}

Uji skala kecil pada LKPD berbasis multimedia interaktif tidak terdapat revisi, hal ini dikarenakan respons peserta didik yang dinyatakan kuat yaitu sebesar 77,28\% dan sudah dapat digunakan sebagai bahan ajar pada materi kingdom monera. Komentar yang peserta didik berikan juga memberikan respons yang baik, sehingga saran yang diberikan tidak ada yang menandakan harus adanya perbaikan. Maka penelitian dilanjutkan ketahap uji skala besar.

Hasil analisis angket respons peserta didik terhadap LKPD berbasis multimedia interaktif pada tahap uji skala besar dapat dilihat pada Tabel 3 berikut:

Tabel 3. Hasil analisis angket respons peserta didik terhadap LKPD berbasis multimedia interaktif pada tahap uji skala besar.

\begin{tabular}{|c|c|c|c|}
\hline \multirow[t]{2}{*}{ Aspek } & \multirow[t]{2}{*}{ Indikator } & \multicolumn{2}{|c|}{ Respons peserta didik } \\
\hline & & $\begin{array}{l}\text { Skala } \\
\text { besar }\end{array}$ & kategori \\
\hline \multirow[t]{3}{*}{ Kognitif } & Kemudahan dalam memahami isi LKPD & $82,67 \%$ & Sangat Kuat \\
\hline & Kesesuaian gambar dan video dengan materi & $79,16 \%$ & Kuat \\
\hline & Kejelasan petunjuk belajar dan informasi di dalam LKPD & $83,33 \%$ & Sangat Kuat \\
\hline
\end{tabular}

Diana Fransiskaa, Laili Fitri Yeni, Titin (Pengembangan LKPD berbasis multimedia interaktif pada materi kingdom monera) 


\begin{tabular}{|c|c|c|c|}
\hline Rata-rata aspek kognitif & & $81,72 \%$ & Sangat Kuat \\
\hline \multirow[t]{3}{*}{ Afektif } & Motivasi & $80,41 \%$ & Kuat \\
\hline & Rasa ingin tahu & $80 \%$ & Kuat \\
\hline & Kemenarikan & $82,91 \%$ & Sangat Kuat \\
\hline Rata-rata aspek afektif & & $81,10 \%$ & Sangat Kuat \\
\hline Konatif & $\begin{array}{l}\text { Kecenderungan untuk menggunakan LKPD berbasis } \\
\text { multimedia interaktif }\end{array}$ & $81,24 \%$ & Sangat Kuat \\
\hline Rata-rata aspek konatif & & $81,24 \%$ & Sangat Kuat \\
\hline Rata-rata keseluruhan & & $81,17 \%$ & Sangat Kuat \\
\hline
\end{tabular}

Hasil uji coba skala kecil dapat dilihat pada Tabel 2 yang diperoleh rata-rata hasil pada aspek kognitif yaitu 78,74\% dengan kategori kuat, aspek afektif memperoleh hasil rata-rata sebesar 77,08\% dengan kategori kuat dan pada aspek konatif memperoleh hasil rata-rata sebesar $76,04 \%$ dengan kategori kuat. Secara keseluruhan uji coba skala kecil memperoleh sebesar rata-rata 77,28\% dengan kategori kuat.

Hasil uji coba skala besar dapat dilihat pada Tabel 3 yang diperoleh hasil rata-rata pada aspek kognitif yaitu sebesar $81,72 \%$ dengan kategori sangat kuat, aspek afektif memperoleh hasil rata-rata sebesar $81,10 \%$ dengan kategori sangat kuat dan pada aspek konatif memperoleh hasil rata-rata sebesar $81,24 \%$ dengan kategori sangat kuat. Secara keseluruhan pada uji skala besar memperoleh hasil ratarata sebesar $81,17 \%$ dengan kategori sangat kuat. Hal ini menunjukkan bahwa peserta didik menyukai LKPD berbasis multimedia interaktif.

\section{Kesimpulan}

Berdasarkan analisis data yang telah dilakukan, maka disimpulkan: (1) Lembar kerja peserta didik berbasis multimedia interaktif pada materi kingdom monera dinyatakan valid sebagai bahan ajar di sekolah dengan nilai CVI (Content Validity Index) sebesar 0,98; (2) Respons peserta didik terhadap Lembar kerja peserta didik berbasis multimedia interaktif pada materi kingdom monera dikategorikan kuat dengan nilai keseluruhan $77,28 \%$ pada tahap uji skala kecil dan $81,17 \%$ dikategorikan sangat kuat pada tahap uji skala besar.

\section{Ucapan Terima Kasih}

Peneliti mengucapkan terimakasih kepada para dosen dan validator yang telah memberikan saran dalam penelitian ini, serta kepada peserta didik yang telah berpartisipasi dan pihak lainnya yang terlibat dalam penyelesaian penelitian ini.

\section{Referensi}

Arahim, I. A. (2018). Pengembangan Lembar Kerja Siswa Dengan Visualisasi Berbantu Macromedia Flash Pada Pembelajaran Matematika. Edukasi: Jurnal Pendidikan, 16(1), 116. https://doi.org/10.31571/edukasi.v16i1.842

Arikunto, S. (2013). Prosedur Penelitian Suatu Pendekatan Praktik. Jakarta: Rineka Cipta.

Branch, R. B. (2009). Instructional Design: The ADDIE Approach. New York: Department of Educational Psychology and Instructional Technology University of Georgia.

Budiman, R. D. A., \& Nurbani. (2019). PENGEMBANGAN MEDIA PEMBELAJARAN 
PENGENALAN SISTEM SISTEM OPERASI BERBASIS ANDROID. Journal of Tropical Chemistry Research and Education, 17(2).

Elwi, L. C., Festiyed, \& Djamas, D. (2017). Pembuatan Lembar Kerja Peserta Didik (LKPD) Multimedia Interaktif Menggunakan Course Lab Berbasis Pendekatan Saintifik Pada Pembelajaran Fisika Kelas X SMA/MA. Pillar of Physics Education, 9(April), 97-104. Retrieved from https://doi.org/10.24036/2521171074

Haryanti, D., Septiana, N., Lestariningsih, N., \& Lestariningsih, N. (2020). Pengembangan Modul Terintegrasi Keislaman Materi Sistem Reproduksi Kelas IX SMPN 4 Katingan Kuala. Journal of Biology Learning, 2(1), 33-40. https://doi.org/10.32585/.v2i1.561

Hasanah, F. N. (2020). Keanekaragaman dan Kemelimpahan Tumbuhan Paku di Cagar Alam Donoloyo sebagai Bahan Pengembangan Multimedia Interaktif Biologi di. Journal of Biology Learning, 2(2), 104-111.

Hasyim, A. (2016). Metode Penelitian dan Pengembangan di Sekolah. Yogyakarta: Media Akademi.

Lawshe, C. H. (1975). a Quantitative Approach To Content Validity. Personnel Psychology, 28(4), 563-575. https://doi.org/10.1111/j.1744-6570.1975.tb01393.x

Manisa, T., Aryati, E., \& Marlina, R. (2018). Respon Siswa Terhadap Lks Berbasis Inkuiri Terbimbing Pada Submateri Sistem Pernapasan Manusia Kelas Xi. Edukasi: Jurnal Pendidikan, 16(1), 1. https://doi.org/10.31571/edukasi.v16i1.771

Munir. (2013). Multimedia Konsep \& Aplikasi dalam Penelitian. Bandung: Alfabeta, CV.

Nufus, H., Khadun, I., \& Nazar, M. (2018). PENGEMBANGAN LEMBAR KERJA PESERTA DIDIK (LKPD) INTERAKTIF BERBASIS SOFTWARE ISPRING PADA MATERI LARUTAN PENYANGGA. In PROSIDING SEMINAR NASIONAL MIPA IV (pp. 46-53). Banda Aceh.

Nurdin, S., \& Andriantoni. (2016). Kurikulum dan Pembelajaran. Depok: Rajagrafino Persada.

Pariska, P. S., Elniati, S., \& Syafriandi. (2012). Pengembangan Lembar Kerja Peserta Didik Matematika Berbasis Masalah. Jurnal Pendidikan Matematika, 1(1).

Prastowo, A. (2015). Panduan Kreatif Membuat Bahan Ajar. Yogyakarta: DIVA Pres.

Prianoto, A. D., Gulo, F., \& Effendi. (2017). PENGEMBANGAN LEMBAR KERJA PESERTA DIDIK (LKPD) INTERAKTIF KIMIA UNTUK PEMBELAJARAN STRUKTUR ATOMDI KELAS X SMA. Jurnal Penelitian Pendidikan Kimia, 4(2), 88-96.

Rahmi, R., Hartini, S., \& Wati, M. (2014). Pengembangan Lembar Kerja Siswa (LKS) Berbasis Inkuiri Terbimbing Dan Multimedia Pembelajaran IPA SMP. Berkala Ilmiah Pendidikan Fisika, 2(2), 173. https://doi.org/10.20527/bipf.v2i2.894

Riduwan. (2015). Skala Pengukuran Variabel-Variabel Penelitian. Bandung: Alfabeta.

Rokhmah, L., Gulo, F., \& Edi, R. (2017). Pengembangan Lembar Kerja Peserta Didik (LKPD) Interaktif Berbasis Komputer untuk Pembelajaran Sistem Periodik Unsur Kelas X SMA Lailatur. In prosiding Seminar Nasional Pendidikan IPA (Vol. 1, pp. 338-347).

Sitepu, B. P. (2015). Penulisan Buku Teks Pembelajaran. Bandung: Remaja Rosdakarya.

Some, I. M. (2013). Pengaruh Penggunaan Macromedia Flash terhadap Minat Belajar Siswa pada Mata Pelajaran Fisika. Jurnal Pendidikan., 2(1).

Subiyantoro, S., \& Nugroho, A. (2018). Android-based Instructional Media Development Procedure to Enhance Teaching and Learning in The Age of Disruption 4.0. In International Conference on Applied Science and Engineering (ICASE 2018) Android-based (Vol. 175, pp. 152-155). Atlantis Press. https://doi.org/10.2991/icase-18.2018.41

Sugiyono. (2015). Metode Penelitian Kuantitatif Kualitatif Dan R\&D. Bandung: Alfabeta.

Syafrizal, S., Yeni, L. F., \& Titin. (2014). Inventarisasi Jamur Makroskopis di Hutan Adat Kantuk dan Implementasinya dalam Pembuatan Flipbook. JURNAL PENDIDIKAN DAN PEMBELAJARAN KHATULISTIWA, 3(9). Retrieved from http://jurnal.untan.ac.id/index.php/jpdpb/article/view/6985/7176

Syamsurizal, Epinur, \& Devi Marzelina. (2017). PENGEMBANGAN LEMBAR KERJA PESERTA DIDIK (LKPD) NON EKSPERIMEN UNTUK MATERI KESETIMBANGAN KIMIA KELAS 
XI IPA SMA N 8 MUARO JAMBI. J. Ind. Soc. Integ. Chem, 6(2). 